\title{
Uncovering the impact of intergenerational income mobility on interpersonal trust
}

\author{
Anna E. Shaleva
}

\section{Correspondence:}

anna.shaleva@jrc.ec.europa.eu European Commission, Joint Research Centre (JRC) - Ispra, Via Enrico Fermi 27/49, 21027 Ispra, Italy

\begin{abstract}
Alluding to theories about relative economic status and behavior, this paper studies if relative income mobility, or the intergenerational change in income positions, affects interpersonal trust. Empirically, the question is brought down to an application with US General Social Survey data. For the identification of a causal relationship, I use a structural approach and estimate a recursive bivariate probit that controls for selection on unobservables. Results suggest that trust increases if children have achieved an upward income movement away from their parents' income position, and it decreases with the experience of downward income mobility. Policy implications are also discussed.

JEL codes: $\mathrm{H} 8 ; \mathrm{O} 4 ; \mathrm{ZOO}$

Keywords: Interpersonal trust; Intergenerational income mobility; Recursive bivariate probit; Selection on unobservables
\end{abstract}

\section{Introduction}

Over the last few decades, trust within societies, known also as interpersonal or social trust, has turned out worthy of increasing attention from both public policy makers and social scientists. Arrow (1974) defines trust as a social lubricant to cooperation and economic exchange, and Putnam (1993) considers it a fundamental building block of social capital. More specifically, Stiglitz (2000) and Millo and Pasini (2010) suggest that interpersonal trust alleviates moral hazard and incentive problems. Empirical evidence confirms the economic theories by finding associations of trust, for example, with investment and transcation costs (Zak and Knack 2002), large organizations' performance (La Porta et al. 1997), and ultimately_by revealing a causal relationship of trust with growth (Algan and Cahuc 2010).

Motivated by the above findings, this paper falls into a branch of the economics literature interested in the factors that influence trust. Regarding determinants at the individual level, Alesina and La Ferrara (2002) find that trust is lower for blacks, women, people with traumatic experience, and those who live in societies with ethnic, race and economic heterogeneity. Zak and Knack (2002) study trust as an outcome of formal/informal institutions, while Aghion et al. (2010) find a negative effect of market regulation on trust. Income inequality is another factor for which previous studies have consistently uncovered an effect on trust. The higher the gap between rich and poor in a society, the 
lower the level of interpersonal trust on both cross-country (Zak and Knack 2001) and cross-community dimensions (Alesina and La Ferrara 2002).

Related literature has implied the interconnection between income mobility and sense of fairness by discussing mobility's relationship with inequality. Solon (2002) suggests that intergenerational income mobility could involve intergenerational transmission of inequality. In the majority of country-level studies, high income mobility is complemented with low cross-section inequality (Gottschalk and Smeeding 1997; Freeman and Katz 1995; and Aaberge et al. 2002 - cited in Solon 2002). Gottschalk (1997) argues that the trend toward greater inequality is to be reduced only if mobility increases. Under a standard approach that assumes all inequalities as unfair, translating the stylized facts on mobility and inequality to mobility and fairness bolsters the speculation that more fairness could be attained also with higher mobility. That said, social trust could be affected by changes in income mobility, and not only by changes in income inequality.

Under a structural approach, controlling for selection on unobservables, this paper aims to uncover a causal relationship between relative intergenerational income mobility and present-day interpersonal trust. The intuition behind is that through changing perceptions of fairness about others and the system, income mobility would affect interpersonal trust. This underlying hypothesis has previously been evidenced in the work of Fischer and Torgler (2006), drawing attention to "envy," a concept that differently from perceptions of fairness has a negative connotation, and showing that people's positional concerns about their relative income correlate negatively with their generalized trust. The authors relate the focus of their study to early origins of economics in moral philosophyfor example, the phenomenon of relative wants is central to human behavior in Adam Smith (1759/1976), and similarly, humans measure their wants and pleasures in relation to society in Marx (1849), while in Marshall (1961) the emphasis is on the relevance of human distinction. ${ }^{1}$ Despite the importance of the question for studying behavior and attitudes, Fischer and Torgler (2006) point to the scant empirical evidence on it.

Except for adding new empirical evidence to the niche and confirming with causal results Fischer and Torgler's (2006) correlation effects on the impact of relative income position on interpersonal trust, more practically, this paper also contributes to the policy debate. Policies aimed at increasing equality of opportunities, creating education opportunities for disadvantaged children and thus increasing upward intergenerational income mobility could be an alternative to income redistribution. The latter could be seen weak in preventing the underpriveleged from remaining so in the long run as they fight against inequality upfronted ex-post, i.e., by taking away from the wealthy to give to the needy. ${ }^{2}$ Based on the results, I can conclude whether the policy option of increasing income mobility would be beneficial for trust.

The availability of US General Social Survey (GSS) data which reports respondents' income, their family income at age 16 along with their current degree of interpersonal trust makes it feasible to identify how trust is affected by the intergenerational change in income position experienced by GSS respondents. For that purpose I construct a simple measure of relative income mobility that equals the difference in income positions achieved by the son/daughter away from their parents' income positions. ${ }^{3}$

The remainder of the paper is organized as follows. Section 2 describes the data, Section 3 presents the econometric specification and the approach for identification. 
Section 4 analyzes the results. Section 5 discusses briefly the policy considerations and Section 6 concludes.

\section{Data}

The US GSS is a unique and valuable data source tracking social behavior and attitudes of Americans since the 1970s. ${ }^{4}$ It is a rich dataset containing information on demographic and socio-economic variables, plus records on special topics of interest. In this paper I use data from the GSS panels 2006, 2008 and 2010, which have the question on "family income at age 16" along with questions on interpersonal trust, current income and the necessary control variables for a TRUST regression analysis. The sample includes 1,205 married respondents (See Appendix: Table 4).

Trust is conventionally measured by recording respondents' answers to the question "Generally speaking would you say that most people can be trusted/you can't be too careful in dealing with people?". The scale includes: 0 if "cannot trust most people", 1 if the answer is "depends" and 2 if "can trust most people".

Past family income is given by respondents' answer to the question: "Thinking about the time when you were 16 years old, compared with American families in general then, would you say your family income was - "far below average", "below average", "average" , "above average", or "far above average" (See Appendix: Table 5). Current respondent income is an inflation adjusted personal income equal to total earnings from all sources in the last year before taxes or other deductions. The variable is within a range of 25 income brackets (See Appendix: Table 6).

I reduce these 25 income positions for current respondent's income by aggregating them to only 5 categories similar to parents' income: "far below average", "below average", "average", "above average", and "far above average." For two definitions of these five categories, the modification follows US Census (2010) categorical division for personal income: first, closely matching the income brackets of the US Census division-constructing Rincome $^{1}$ and, secondly, modifying the categories "far below average", "below average" and "average" mainly by expanding the percentage for the category "average" to mirror the corresponging bigger share also for parents'/past family income with the resulting variable Rincome ${ }^{2}$. For the third definition of current income, I match the category distribution of past family income by creating similar in percentage share categories for respondent's income-thus, constructing Rincome ${ }^{3}$ (See Appendix: Table 7). With each of these simplified measures for current respondent's income, I obtain the corresponding indices for income mobility that equal the difference of present individual income position and "family income position at age 16" (See Appendix: Table 8). IMind $x^{\mathrm{i}}$ for $\mathrm{i}=1,2$ and 3 captures how incomes are correlated across periods: IMind $x^{\mathrm{i}}=0$ implies intergeneralational income correlation $\simeq 1$ (i.e., persistence of income), IMind $x^{\mathrm{i}}>0$ \& IMind $x^{\mathrm{i}}<0$ imply correlation $<1$, whereas IMind $x^{\mathrm{i}} \gg 0$ and IMind $x^{\mathrm{i}} \ll 0$ imply correlation $\simeq 0$ (i.e., substantial intergenerational income change). IMind $x^{\mathrm{i}}$ is an intermediate variable which I use as a basis for the construction of binary dummies for income mobility but do not include in the regression analysis.

\section{Econometric specification}

\subsection{Recursive bivariate probit model: selection on unobservables}

The empirical challenge for identifying a causal effect of income mobility on trust is to 
deal with the endogeneity of income mobility potentially stemming from selection on unobservables. That is, unobservables, such as perceptions of the system's fairness and the subsequent motivation or optimistic/pessimistic attitudes, could determine the chance to achieve a change in parents' income position but could also affect interpersonal trust.

I adopt a structural approach under which the outcome equation for TRUST includes intergenerational income mobility as an endogenous binary regressor. ${ }^{5}$ Blundell and Smith (1993) describe type I and type II specifications of the bivariate probit model. Since I want to identify the impact of having achieved income mobility on trust rather than the impact of the propensity to achieve income mobility, the type II specification is the appropriate one. The coherency conditions for the type II model are fulfilled only when the model is specified as a recursive system. With the retrospective nature of this studythe outcome is contemporary trust and the explanatory variable, income mobility, has been realized prior to reporting trust perceptions-a recursive system highlights that what is under scrutiny is the causal direction from mobility to trust, and not vice versa. In that way, it is clear that the endogeneity of intergenerational income mobility stems from unobservable heterogeneity bias rather than from a direct effect of trust on the chance to achieve income mobility.

$$
\begin{aligned}
& \text { TRUST }=x_{2 i}^{\prime} \beta_{2}+\mu I M I+\varepsilon_{2 i} \\
& I M I=x_{1 i}^{\prime} \beta_{1}+\varepsilon_{1 i}
\end{aligned}
$$

Selection effects are modelled with a common factor specification of the error terms:

$$
\varepsilon_{2 i}=\rho v_{i}+u_{2 i}
$$

$$
\varepsilon_{1 i}=\rho v_{i}+u_{1 i}
$$

The error terms are distributed as bivariate standard normal $\left[\varepsilon_{1 i}, \varepsilon_{2 i}\right] \sim \Phi_{2}(0,0, \rho)$, where the first two arguments of $\Phi_{2}$ are the means of $\varepsilon_{1 i}$ and $\varepsilon_{2 i}, \rho$ is the correlation between $\varepsilon_{1 i}$ and $\varepsilon_{2 i}$, and $v_{i}$ represents unobserved heterogeneity. IMI is an endogenous explanatory variable if the correlation between $\varepsilon_{1 i}$ and $\varepsilon_{2 i}$ is different from zero, i.e., IMI is endogenous if $\rho \neq 0$.

As Jones (2005) explains, the sufficient condition for identification in this recursive system is variation in the set of exogenous regressors since identification occurs by functional form. Although exclusion restrictions are not needed, it is common practice to impose them for improving identification.

I estimate two versions of the model just presented by changing only the definition of the binary dummy for income mobility. First, $I M I$ compares any type of income mobility, captured by $I M I=1$ if IMind $\neq \neq 0$, with the absence of income change over generations, i.e., $I M I=0$ based on IMind $x=0$. Second, rather than generally representing income change with $I M I$, I define two cases for upward and downward income mobility. For upward mobility $I M I^{U}=1$ if $I M i n d x>0$, and $I M I^{U}=0$ for persistence of intergenerational income positions, i.e., $I M i n d x=0$. Reversely, for downward mobility $I M I^{D}=1$ if $I$ Mind $x<0$, and $I M I^{D}=0$ when IMind $x=0$ for lack of mobility. The binary outcome variable TRUST is the same across the two model versions: TRUST $=1$ if TRUST $>0$, 
i.e., if "can trust most people," and TRUST $=0$ if the answer is "cannot trust" or "depends." The explanatory variables $x_{1 i}^{\prime}$ and $x_{2 i}^{\prime}$ satisfy the condition $x_{1 i}^{\prime}=\left(x_{2 i}^{\prime}, z_{1 i}\right) \perp\left(\varepsilon_{1 i}, \varepsilon_{2 i}\right)$.

\subsection{Exclusion Restrictions}

To avoid relying too heavily on the assumption of bivariate normality for identification by functional form, I incorporate into the analysis a key identifying variable $z_{1 i}$ to fulfill the exclusion restrictions. But even so, the recursive system is a joint model for trust and income mobility, and not a standard two-step IV approach. The coherency or the logical consistency of the econometric model remains the main pre-requisite for identification.

Since it is necessary that $z_{1 i}$ is correlated with the binary dummies for mobility $I M I$, $I M I^{U}$ and $I M I^{D}$, and is also independent from $\varepsilon_{2 i}$, I use for it a variable that measures the difference between respondent's spouse occupation prestige score and the occupation prestige score of respondent's mother (Diffspousemother). For example, according to a 1989 GSS study of occupational prestige classification (Davis et al. 1991), physicians gain the maximum prestige score while miscellanous food preparation occupations rank the lowest (See Appendix: Table 11). Predicting income with occupation prestige scores is a working approach, as demonstrated by several studies (e.g, Ermisch et al. 2006; Feigenbaum 2014; and Mazumder and Acosta 2015). Occupation prestige scores here would also be proxies for income, so their difference would proxy intergenerational income change. Correlations of the components of Diffspousemother with income mobility provide preliminary statistical justification for using Diffspousemother as a key identifying variable (See Appendix: Table 10). In what follows, I discuss how Diffspousemother would satisfy the exclusion restrictions.

A growing body of research suggests purposeful positive assortative mating in the marriage market. For example, Chadwick and Solon (2002) find evidence for matching with respect to earnings, Chiappori et al. (2009) show that for $50 \%$ of the married couples in their sample the husband and wife have the same level of schooling, and similarly Ermisch et al. (2006) evidence assortative mating along human capital. Simple correlation analysis (See Appendix: Table 9) implies the possible assortative mating characterizing married respondents in the GSS sample: $46.6 \%$ is the correlation between the respondent's and the spouse's highest degrees and $54.7 \%$ between the respondent's and the spouse's years of schooling. Likewise, spouse's occupation prestige score is moderately correlated with respondent's occupation prestige score (30.6\%), and mother's occupation prestige score correlates with father's occupation prestige score (38.4\%). That said, spouse's occupation prestige score should make a good predictor of respondent's current income position, while mother's occupation prestige score should proxy father's income position and, indirectly, the family's income situation of the respondent at age 16 . With valid components, the variable Diffspousemother becomes a credible predictor of intergenerational income mobility, in line with the first exclusion restriction.

A challenge in the analysis is the possible dependence of Diffspousemother from the unobservables included in $\varepsilon_{2 i}$, i.e., explanatory factors for TRUST. It is not straightforward to conclude the contrary, so I discuss the main arguments of controversy. Even though assigned by an external actor, such as a government agency, occupation prestige scores could reflect perceptions of both the professionals having the scores assigned and society as an observer of prestige and status. For example, Paxton (2007) finds a positive effect of occupation prestige score on the predicted probability of generalized 
(interpersonal) trust. Allusive of that finding is Ermisch and Gambetta's (2011) result showing that sons' trustworthiness, even though not exactly trust, is affected positively by fathers' occupation prestige score if high. The same question, but studied vice versa, is also found in Piff et al. (2010), with the hypothesis that "lower class" people (with lower occupation prestige score) are more concerned with the needs of others than "upper class" people, and so will act in a more pro-social manner to improve others' welfare.

Not excluding the possibility that occupation prestige scores reflect individual differences in trust, I elaborate on each of the components of the variable Diffspousemother by explaining the related caveats for dependence with the unobservables shaping trust. Since I use mother's occupation prestige score to proxy parents' income, the first concern is whether transmission of trust-related unobservables from mother to child takes place. I should acknowledge that the evidence on this is controversial-for example, using data from a German Socio-Economic Panel Study, Dohmen et al. (2012) find that trust attitudes are transferred from parents to children. In contrast, relying on a sample of 377 twins, Van Lange et al. (2014) reveal that genetic influences are almost absent from trust and more modest than that of various expressions of abilities and personality traits. The authors' findings challenge the law in behavior genetics according to which all human behavioral traits are quite heritable. They emphasize that what shapes "trust in others" is the social interaction experiences outside of the immediate family.

The concern related with the second component of Diffspousemother, spouse's occupation prestige score, is about possible assortative mating along the dimension of trust. Indeed, this may happen, as already demonstrated by Dohmen et al. (2012). Nevertheless, Luo and Klohnen (2005) show positive similarities of married individuals for attitudes other than trust (e.g, religiosity, political attitudes) with dissimilarities for personal traits such as extraversion, openness and avoidance. It appears that the personal traits just mentioned would be related to "trust in others," and thus depending on the definition of trust, Dohmen et al's (2012) findings could be easily complemented with opposing results. Moreover, going back to the findings of Van Lange et al. (2014), what matters for trust is the direct personal experience in social interactions, and even the shared spouses' environment is not expected to cause similarity in spouses' generalized trust. Indeed, genetics could be a factor for partners' matching (Domingue et al. 2014), but if genes do not affect generalized trust, then partners could be genetically similar and still dissimilar in their "trust in others". Even if some controversy might remain on whether Diffspousemother fulfills fully the exclusion restrictions, referring to Jones (2005), I recall that in the recursive system identification can be achieved just by functional form.

\section{Results}

The evidence convincingly demonstrates a causal effect of intergenerational (relative) income mobility on interpersonal trust. Starting with a general model for income change, regardless of whether it is upward or downward, the binary dummy $I M I$ is highly significant in all model estimations (See Table 1). With an IMindx ${ }^{1}$-based IMI in column (1), I obtain a negative sign for the main effect of interest, but this result should be considered with caution as IMind $x^{1}$ may not be a realistic measure given that it reflects perfectly the US Census division of personal income, including a very small share for "average" income. Varying IMind $x^{1}$ by extending the percentage share of the "average" personal income, i.e., using $I M i n d x^{2}$-based IMI, I obtain an intuitive positive result from the estimation in 
Table 1 Trust and relative income mobility (upward/downward)

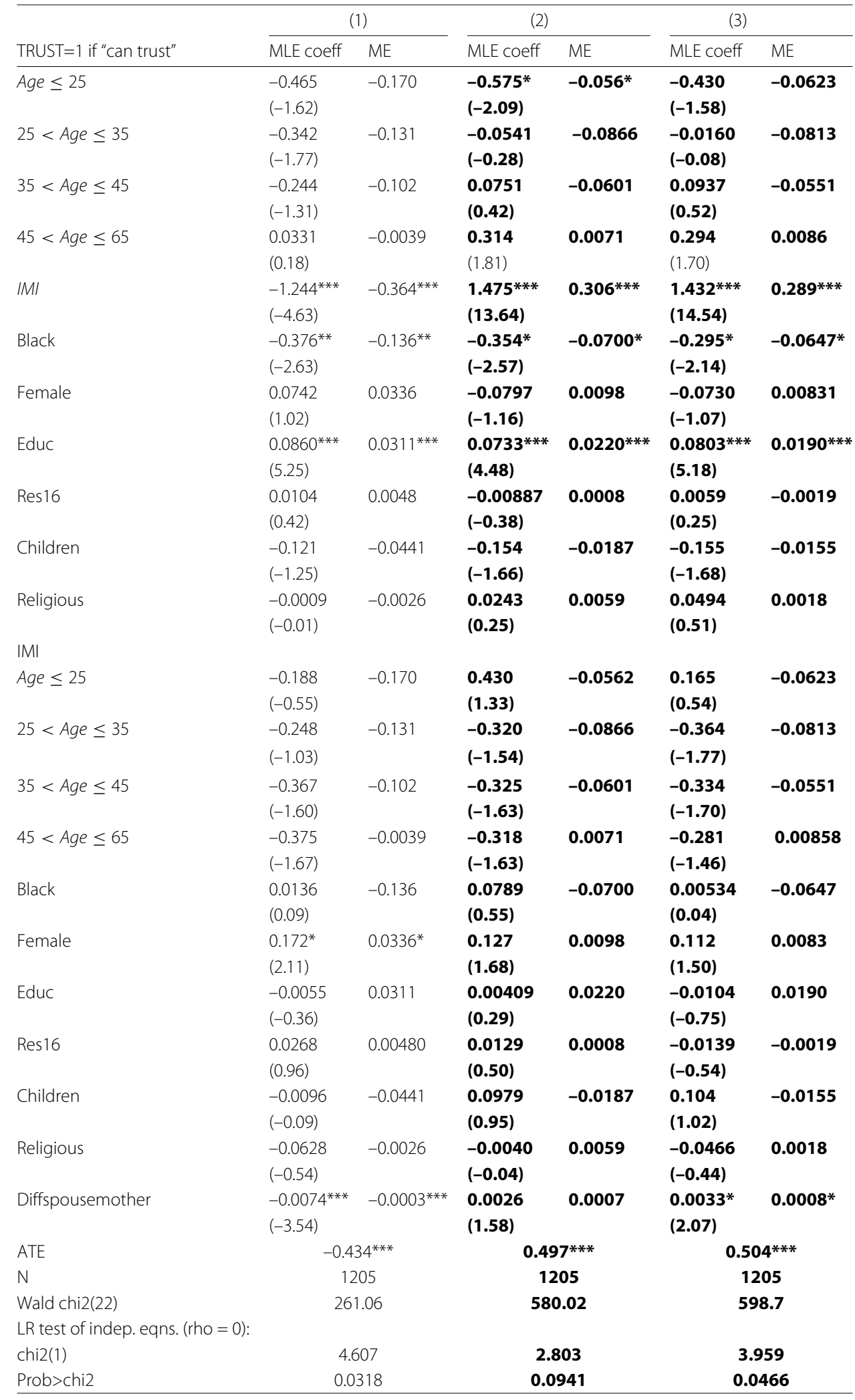

Note: Biprobit fits a maximum-likelihood two-equation probit models of the binary variables TRUST and IMI

ME stands for Marginal Effects; $t$ statistics in parentheses. In estimations (1) through (3) the binary dummy IMI is based on the differently defined indice $I M i n d x^{1}, I M i n d x^{2}$ and $I$ Mind $x^{3}$. Preferred estimations are printed in bold font

${ }^{*} p<0.05,{ }^{* *} p<0.01,{ }^{* * *} p<0.001$ 
column (2). Moreover, this result gets confirmed by the estimation in column (3), using an IMind $x^{3}$-based IMI. The estimated average treatment effect (ATE) is around 0.50 when the effect of income mobility on trust is positive, implying that trust is increased by $50 \%$ if income mobility is present, relative to a situation in which intergenerational income positions stay stable. The secondary results on individual-level controls for trust are consistent with previous literature: an additional year of education is related with an increase in the probability of trust by $2-3 \%$; race, if "black", correlates negatively with trust; very young respondents trust less, with the marginal effect (ME) associated with the dummy Age $<25$ equal to -0.05 ; while females are more trusting $(\mathrm{ME}=0.03)$. The statistical properties, listed at the bottom of Table 1, confirm the overall satistical significance of the model for the estimations (1) and (3). The null hypothesis of independent equations $($ rho $=0)$ is rejected with the values for Prob $>$ chi2 less than 0.05, implying that $\rho \neq 0$, and that the bivariate probit model is appropriate.

Intuitively, I expect that positive and negative intergenerational income changes would affect trust differently, and hence, it is important to distinguish between them. As with the generally defined income change, $I M I$, in defining the dummies capturing upward and downward mobility-IMIup and IMIdown-the baseline case is one of persistence of parents' income positions. Compared to the general income mobility model, the separate models make it possible to get more precise estimates of intergenerational change in income influences on trust and subsequently of calculating more accurately the net causal effect of income mobility. The reason for that is that in comparing more homogenous groups, i.e., only those having experienced either downward or upward mobility with those with no income mobility, I can eliminate any bias coming from equally treating downward and upward income movements. Confirming intuition, the estimated ATE for IMIup is different in sign and size from the ATE for IMIdown (See Tables 2 and 3). Precisely, reading the robust results from columns (2) and (3), upward income mobility causes an increase of $35 \%$ in the probability of trust (ATE $=0.35$ ) while downward mobility decreases it by around $30-32 \%$. Thus, the resulting net ATE effect is equal to $3-5 \%$. This result, along with the preliminary indication of a positive causal relationship between $I M I$ and trust (See Table 1), is essential for conclusions as well as for policy implications.

Consistent with the initial predictions, in the separate model estimations, the probability of trust remains lower for black respondents and higher for the more educated (See Tables 2 and 3). In the sample focusing on "downward income movers," black respondents appear to have four times lower probablity of trust $(M E \approx 10-12 \%)$ than black respondents in the sample including the "upward income movers" $(M E \approx 3 \%)$. That distinction does not hold for education as an additional year of education seems to increase the probability of trust by $1-2 \%$ regardless of the type of income mobility experienced. Besides, age turns out significant only in the estimation for "upward income movers," suggesting a 5\% increase in the probability of trust with one more year of age. But also, this effect would be decreasing over time as the squared term for age has a negative significant effect. Being female positively correlates with downward income change, while the evidence for gender and upward income change is weaker and inconclusive.

Finally, it is worth commenting whether the initial ambiguity on the sign of the income mobility effect has been resolved through decomposing positive and negative income change. For downward mobility, results are robust and convincingly suggest a negative causal impact. Whereas, for upward income mobility, when using IMIup based 
Table 2 Trust and upward income mobility

\begin{tabular}{|c|c|c|c|c|c|c|}
\hline \multirow[b]{2}{*}{ TRUST=1 if "can trust" } & \multicolumn{2}{|c|}{ (1) } & \multicolumn{2}{|l|}{ (2) } & \multicolumn{2}{|l|}{ (3) } \\
\hline & MLE coeff & ME & MLE coeff & ME & MLE coeff & ME \\
\hline \multirow[t]{2}{*}{ Age } & $0.128^{* * *}$ & $0.0566^{* * *}$ & 0.0139 & 0.0114 & 0.00915 & 0.0150 \\
\hline & $(-3.34)$ & & $(0.46)$ & & $(0.30)$ & \\
\hline \multirow[t]{2}{*}{ Agesq } & $-0.00114^{* *}$ & $-0.0005^{* *}$ & -0.0001 & -0.0001 & -0.0000 & -0.0001 \\
\hline & $(-2.90)$ & & $(-0.22)$ & & $(-0.03)$ & \\
\hline \multirow[t]{2}{*}{ IMlup } & $-1.200^{* * *}$ & $-0.211^{* * *}$ & $1.466 * * *$ & $0.225^{* * *}$ & $1.368^{* * *}$ & $0.216 * * *$ \\
\hline & $(-17.17)$ & & $(7.92)$ & & $(6.60)$ & \\
\hline \multirow[t]{2}{*}{ Black } & -0.387 & -0.106 & $-0.517 * *$ & $-0.0323 * *$ & $-0.455^{* *}$ & $-0.0377^{* *}$ \\
\hline & $(-1.78)$ & & $(-3.04)$ & & $(-2.78)$ & \\
\hline \multirow[t]{2}{*}{ Female } & -0.0994 & -0.0752 & 0.130 & -0.0047 & 0.0940 & -0.0061 \\
\hline & $(-0.96)$ & & $(1.55)$ & & (1.15) & \\
\hline \multirow[t]{2}{*}{ Educ } & $0.0864^{* * *}$ & $0.0291^{* * *}$ & $0.0557^{*}$ & $0.0113^{*}$ & $0.0698 * * *$ & $0.0125 * * *$ \\
\hline & $(-4.78)$ & & $(2.40)$ & & $(3.31)$ & \\
\hline \multirow[t]{2}{*}{ Res16 } & 0.0405 & 0.0226 & -0.0096 & 0.0019 & 0.0240 & 0.0002 \\
\hline & $(-1.18)$ & & $(-0.34)$ & & $(0.88)$ & \\
\hline \multirow[t]{2}{*}{ Children } & -0.0932 & -0.0185 & -0.106 & -0.0137 & -0.144 & -0.0149 \\
\hline & $(-0.65)$ & & $(-0.93)$ & & $(-1.30)$ & \\
\hline \multirow[t]{2}{*}{ Religious } & 0.0072 & -0.0169 & 0.0507 & 0.0051 & 0.0629 & 0.0014 \\
\hline & $(-0.05)$ & & $(0.42)$ & & $(0.54)$ & \\
\hline \multicolumn{7}{|l|}{ IMlup } \\
\hline \multirow[t]{2}{*}{ Age } & $0.151^{* *}$ & $0.0566^{* *}$ & $0.0675^{*}$ & $0.0114^{*}$ & $0.0899 * *$ & $0.0150 * *$ \\
\hline & $(-3.21)$ & & $(2.36)$ & & $(3.21)$ & \\
\hline \multirow[t]{2}{*}{ Agesq } & $-0.0014^{* *}$ & $-0.0005^{* *}$ & $-0.0006^{*}$ & $-0.0001 *$ & $-0.0008 * *$ & $-0.0001 * *$ \\
\hline & $(-2.95)$ & & $(-2.02)$ & & $(-2.87)$ & \\
\hline \multirow[t]{2}{*}{ Black } & 0.021 & -0.106 & 0.222 & -0.0323 & 0.145 & -0.0377 \\
\hline & $(-0.09)$ & & $(1.31)$ & & $(0.91)$ & \\
\hline \multirow[t]{2}{*}{ Female } & $-0.239^{*}$ & $-0.0752^{*}$ & -0.163 & -0.0047 & -0.133 & -0.0061 \\
\hline & $(-2.03)$ & & $(-1.78)$ & & $(-1.53)$ & \\
\hline \multirow[t]{2}{*}{ Educ } & $0.0653^{* *}$ & $0.0291 * *$ & 0.0255 & 0.0113 & 0.0130 & 0.0125 \\
\hline & $(-3.21)$ & & $(1.54)$ & & $(0.84)$ & \\
\hline \multirow[t]{2}{*}{ Res16 } & 0.0665 & 0.0226 & 0.0230 & 0.0019 & -0.0222 & 0.0002 \\
\hline & $(-1.71)$ & & $(0.75)$ & & $(-0.76)$ & \\
\hline \multirow[t]{2}{*}{ Children } & -0.0239 & -0.0185 & 0.0126 & -0.0137 & 0.0479 & -0.0149 \\
\hline & $(-0.15)$ & & $(0.10)$ & & $(0.40)$ & \\
\hline \multirow[t]{2}{*}{ Religious } & -0.083 & -0.0169 & -0.0131 & 0.0051 & -0.0534 & 0.0014 \\
\hline & $(-0.49)$ & & $(-0.10)$ & & $(-0.43)$ & \\
\hline \multirow[t]{2}{*}{ Diffspousemother } & -0.0044 & -0.0010 & 0.0036 & 0.0005 & $0.0050^{*}$ & $0.0007^{*}$ \\
\hline & $(-1.81)$ & & (1.76) & & $(2.40)$ & \\
\hline ATE & -0.1 & $4^{* * *}$ & 0.3 & $56 * * *$ & 0.34 & $9 * * *$ \\
\hline $\mathrm{N}$ & & & & 04 & & 73 \\
\hline Wald chi2(18) & & & & 7.34 & 34 & .32 \\
\hline LR test of indep. eqns. & & & & & & \\
\hline $\operatorname{chi2}(1)$ & & & & 562 & & 38 \\
\hline Prob>chi2 & & & & 1095 & 0.0 & 472 \\
\hline
\end{tabular}

Note: Biprobit fits a maximum-likelihood two-equation probit models of the binary variables TRUST and IMlup

ME stands for Marginal Effects; $t$ statistics in parentheses. In estimations (1) through (3) the binary dummy IMI is based on the differently defined indice IMind $x^{1}$, Mind $x^{2}$ and IMindx $x^{3}$. Preferred estimations are printed in bold font

${ }^{*} p<0.05,{ }^{* *} p<0.01,{ }^{* * *} p<0.001$

on IMindx $x^{1}$, the negative result is counter-intuitive and inconsistent with the positive findings based on IMind $x^{2}$ and IMind $x^{3}$. An explanation for this estimate is the likely fault of the income mobility index, IMind $x^{1}$, to reflect the actual/realistic income distribution 
Table 3 Trust and downward income mobility

\begin{tabular}{|c|c|c|c|c|c|c|}
\hline \multirow{2}{*}{ TRUST=1 if "can trust" } & \multicolumn{2}{|c|}{ (1) } & \multicolumn{2}{|l|}{$(2)$} & \multicolumn{2}{|l|}{ (3) } \\
\hline & MLE coeff & $\mathrm{ME}$ & MLE coeff & ME & MLE coeff & ME \\
\hline \multirow[t]{2}{*}{ Age } & 0.0238 & 0.00395 & -0.0217 & -0.0242 & -0.0158 & -0.0268 \\
\hline & $(0.99)$ & & $(-0.82)$ & & $(-0.56)$ & \\
\hline \multirow[t]{2}{*}{ Agesq } & -0.0001 & -0.0000 & 0.0003 & 0.0003 & 0.0003 & 0.0003 \\
\hline & $(-0.52)$ & & $(1.21)$ & & $(0.99)$ & \\
\hline \multirow[t]{2}{*}{ IMldown } & $-1.238^{* * *}$ & $-0.357^{* * *}$ & $-1.260 * * *$ & $-0.251 * * *$ & $-1.242^{* * *}$ & $-0.212^{* * *}$ \\
\hline & $(-4.77)$ & & $(-9.12)$ & & $(-6.67)$ & \\
\hline \multirow[t]{2}{*}{ Black } & $-0.362^{*}$ & $-0.125^{*}$ & -0.268 & -0.0769 & $-0.397^{*}$ & $-0.105^{*}$ \\
\hline & $(-2.26)$ & & $(-1.59)$ & & $(-2.29)$ & \\
\hline \multirow[t]{2}{*}{ Female } & $0.177^{*}$ & $0.0781^{*}$ & $0.239 * *$ & $0.119 * *$ & $0.234^{*}$ & $0.128 *$ \\
\hline & $(2.10)$ & & $(2.77)$ & & $(2.51)$ & \\
\hline \multirow[t]{2}{*}{ Educ } & $0.0706^{* * *}$ & $0.0224^{* * *}$ & $0.0620 * *$ & $0.0093^{* *}$ & $0.0545^{*}$ & $-0.0009 *$ \\
\hline & $(3.52)$ & & $(3.02)$ & & $(2.32)$ & \\
\hline \multirow[t]{2}{*}{$\operatorname{Res} 16$} & 0.0287 & 0.0111 & 0.0097 & 0.0021 & 0.00958 & 0.0015 \\
\hline & $(1.04)$ & & $(0.34)$ & & $(0.32)$ & \\
\hline \multirow[t]{2}{*}{ Children } & -0.211 & -0.0731 & -0.115 & 0.0031 & -0.134 & -0.0023 \\
\hline & $(-1.96)$ & & $(-0.98)$ & & $(-1.13)$ & \\
\hline \multirow[t]{2}{*}{ Religious } & -0.0334 & -0.0129 & -0.0358 & -0.0037 & -0.0308 & -0.0141 \\
\hline & $(-0.29)$ & & $(-0.31)$ & & $(-0.25)$ & \\
\hline \multicolumn{7}{|l|}{ IMldown } \\
\hline \multirow[t]{2}{*}{ Age } & $-0.0782^{* *}$ & $0.0039 * *$ & $-0.111 * * *$ & $-0.0242 * * *$ & $-0.112 * * *$ & $-0.0268^{* * *}$ \\
\hline & $(-3.21)$ & & $(-4.98)$ & & $(-5.00)$ & \\
\hline \multirow[t]{2}{*}{ Agesq } & $0.0008^{* *}$ & $-0.0000^{* *}$ & $0.0012^{* * *}$ & $0.0003^{* * *}$ & $0.0012^{* * *}$ & $0.0003 * * *$ \\
\hline & $(3.10)$ & & $(4.96)$ & & $(5.10)$ & \\
\hline \multirow[t]{2}{*}{ Black } & -0.0098 & -0.125 & -0.100 & -0.0769 & -0.203 & -0.105 \\
\hline & $(-0.06)$ & & $(-0.56)$ & & $(-1.10)$ & \\
\hline \multirow[t]{2}{*}{ Female } & $0.319^{* * *}$ & $0.0781^{* * *}$ & $0.387^{* * *}$ & $0.119 * * *$ & $0.426 * * *$ & $0.128 * * *$ \\
\hline & $(3.63)$ & & $(4.35)$ & & $(4.60)$ & \\
\hline \multirow[t]{2}{*}{ Educ } & $-0.0354^{*}$ & $0.0224^{*}$ & -0.0229 & 0.0093 & $-0.0448^{*}$ & $-0.0009 *$ \\
\hline & $(-2.11)$ & & $(-1.35)$ & & $(-2.49)$ & \\
\hline \multirow[t]{2}{*}{ Res16 } & 0.0214 & 0.0111 & 0.0003 & 0.0021 & -0.0004 & 0.0015 \\
\hline & $(0.70)$ & & $(0.01)$ & & $(-0.01)$ & \\
\hline \multirow[t]{2}{*}{ Children } & -0.0229 & -0.0731 & 0.121 & 0.0031 & 0.0726 & -0.0023 \\
\hline & $(-0.19)$ & & $(1.02)$ & & $(0.60)$ & \\
\hline \multirow[t]{2}{*}{ Religious } & -0.0251 & -0.0129 & 0.0206 & -0.0037 & -0.0421 & -0.0141 \\
\hline & $(-0.19)$ & & $(0.16)$ & & $(-0.32)$ & \\
\hline \multirow[t]{2}{*}{ Diffspousemother } & $-0.0085^{* * *}$ & $-0.0004^{* * *}$ & $-0.0043 *$ & $-0.0008^{*}$ & $-0.0047^{*}$ & $-0.0010 *$ \\
\hline & $(-3.74)$ & & $(-2.25)$ & & $(-2.27)$ & \\
\hline ATE & -0.3 & $53^{* * *}$ & -0.2 & $96 * *$ & -0.3 & $18^{* * *}$ \\
\hline N & & 53 & & 44 & & 07 \\
\hline Wald chi2(18) & & 7.99 & & 1.67 & & 8.23 \\
\hline LR test of indep. eqns. & & & & & & \\
\hline $\operatorname{chi} 2(1)$ & & 598 & & 605 & & 371 \\
\hline Prob>chi2 & & 170 & 0.0 & 319 & & 366 \\
\hline
\end{tabular}

Note: Biprobit fits a maximum-likelihood two-equation probit models of the binary variables TRUST and IMIdown

ME stands for Marginal Effects; t statistics in parentheses. In estimations (1) through (3) the binary dummy IMI is based on the differently defined indice $I$ Mind $x^{1}, M_{\text {Mind }}{ }^{2}$ and $I$ Mind $x^{3}$. Preferred estimations are printed in bold font

${ }^{*} p<0.05,{ }^{* *} p<0.01,{ }^{* * *} p<0.001$

of GSS respondents. Observing the significance of the identifying variable Diffspousemother only in the estimation with IMind $x^{3}$-based IMIup helps in highlighting as more credible the positive IMIup effect. Moreover, among the three estimations on IMIup, in accordance with the Likelihood ratio test, the overall significance of the model is best captured by the IMindx ${ }^{3}$-based estimation.

In relation to the cited theories on relative economic status in Fischer and Torgler (2006), the current evidence suggests the implicit linkage between generalized trust 
and perceptions of fairness through income mobility. Low current income position, or downward income mobility, and the expected, but unobserved, perceptions of others' unfairness would explain low generalized trust, while high income position, or upward income mobility, and positive perceptions of others would explain high generalized trust.

\section{Policy Implications}

Increasing income mobility, as defined here in relative terms, would entail a change in the percentage shares of both up and down income "movers," i.e., there will be winners and losers. Overall, however, social trust will be favorably affected if there is more intergenerational income volatility rather than if income positions were passed down from parents to children. The identified causality could be interpreted in terms of unobserved system's fairness and the perceptions arising from it. An environment that encourages education and equal opportunities would be conducive for trust through actual income mobility, among other possible channels. Regarding social trust, these results connect with existing evidence on the effects of education and social homogeneity while implicitly also suggesting equality of opportunity as another source of homogeneity for trust.

\section{Conclusions}

The evidence on income inequality and relative economic status on behavior and attitudes is still rare. Another way to study income inequality is to think about intergenerational income mobility. The way income mobility affects generalized trust could be quite informative for understanding the general impact of income mobility on the economy. The contribution of the paper is two-fold: first, it provides evidence for a causal relationship between the relative/intergenerational change in income positions and trust, and second, it makes it possible to consider income mobility policies as a feasible alternative to income redistribution. Results suggest that trust is affected positively when children have achieved an upward movement from their parents' income position, while it is decreased by the experience of downward income mobility. The majority of the findings are robust to a change of the definition of the income mobility measure. With a resulting positive net effect of income mobility, the paper recommends policies aimed at equality of opportunities and education. Further research could check the validity of these results with absolute income mobility measures and, if possible, also extend it beyond the US case.

\section{Endnotes}

${ }^{1}$ Adam Smith (1759/1976), Marx (1849) and Marshall (1961) are cited in Fischer and Torgler (2006).

${ }^{2}$ Thurow's (1973) reasons for inefficient and ineffective income redistribution are: insufficiently distinguished means and ends, difficulty to come up with a consistent decision on the alteration of the income distribution, inevitable infringement of property rights and internal policy contradictions. Prompted by the need to explain the puzzle of inefficient redistribution, Acemoglu and Robinson (2001) develop a theory model in which inefficient redistribution could be a tool to sustain political power.

${ }^{3}$ Previous studies have focused on inter-generational father-son or father-daughter correlation of earnings (Solon 1992; Chadwick and Solon 2002).

${ }^{4}$ GSS data is referenced as Smith et al. (2013).

${ }^{5}$ The model specification follows the description of a recursive biprobit model in Jones (2005). 


\section{Appendix}

Table 4 Summary statistics

\begin{tabular}{|c|c|c|c|c|c|}
\hline Variable & $\mathrm{N}$ & Mean & Std. Dev. & Min. & Max. \\
\hline TRUST & 1,205 & 0.46 & 0.499 & 0 & 1 \\
\hline$=0$ if "cannot trust" or "depends" & 651 & & & & \\
\hline$=1$ if "can trust" & 554 & & & & \\
\hline Age $\leq 25$ & 1,205 & 0.028 & 0.166 & 0 & 1 \\
\hline $25<$ Age $\leq 35$ & 1,205 & 0.195 & 0.396 & 0 & 1 \\
\hline $35<$ Age $\leq 45$ & 1,205 & 0.284 & 0.451 & 0 & 1 \\
\hline $45<$ Age $\leq 65$ & 1,205 & 0.452 & 0.498 & 0 & 1 \\
\hline Age $>65$ & 1,205 & 0.0407 & 0.197 & 0 & 1 \\
\hline Age & 1,205 & 45.468 & 11.694 & 19 & 88 \\
\hline Black & 1,205 & 0.074 & 0.262 & 0 & 1 \\
\hline$=0$ if "white" or "other" & 1,116 & & & & \\
\hline$=1$ if "black" & 89 & & & & \\
\hline Female & 1,205 & 0.504 & 0.5 & 0 & 1 \\
\hline$=0$ if "male" & 598 & & & & \\
\hline$=1$ if "female" & 607 & & & & \\
\hline Educ (years of education) & 1,205 & 14.524 & 2.741 & 2 & 20 \\
\hline $\operatorname{Res} 16$ & 1,205 & 3.466 & 1.456 & 1 & 6 \\
\hline$=1$ if "country,nonfarm" & 152 & & & & \\
\hline$=2$ if "farm" & 100 & & & & \\
\hline$=3$ if "town lt 50000" & 425 & & & & \\
\hline$=4$ if "50000 to $250000 "$ & 222 & & & & \\
\hline = 5 if "big-city suburb" & 174 & & & & \\
\hline$=6$ if "city gt 250000" & 132 & & & & \\
\hline Children & 1,205 & 0.829 & 0.377 & 0 & 1 \\
\hline$=0$ if "no children" & 206 & & & & \\
\hline$=1$ if "children" & 999 & & & & \\
\hline Religious & 1,205 & 0.856 & 0.352 & 0 & 1 \\
\hline$=0$ if "not religious" & 174 & & & & \\
\hline$=1$ if "religious" & 1,031 & & & & \\
\hline Spouse prestige score & 1,205 & 46.753 & 13.458 & 17 & 86 \\
\hline Mother prestige score & 1,205 & 43.183 & 14.309 & 17 & 86 \\
\hline Diffspousemother & 1,205 & 3.569 & 17.686 & -54 & 55 \\
\hline
\end{tabular}

Table 5 Categories of family income at age 16

\begin{tabular}{lll}
\hline Fincome (age 16) categories & Frequency & $\%$ \\
\hline$=1$ "Far Below Average" & 81 & 6.72 \\
$=2$ "Below Average" & 257 & 21.33 \\
$=3$ "Average" & 587 & 48.71 \\
$=4$ "Above Average" & 270 & 22.41 \\
$=5$ "Far Above Average" & 10 & 0.83 \\
Total & $N=1,205$ & 100 \\
\hline
\end{tabular}


Table 6 Respondents' income (Rincome) as of survey year (2006, 2008 \& 2010)

\begin{tabular}{lcc}
\hline under 1000 & 17 & 1.41 \\
\hline 1000 to 2999 & 21 & 1.74 \\
3000 to 3999 & 12 & 1 \\
4000 to 4999 & 16 & 1.33 \\
5000 to 5999 & 16 & 1.33 \\
6000 to 6999 & 9 & 0.75 \\
7000 to 7999 & 8 & 0.66 \\
8000 to 9999 & 26 & 2.16 \\
10000 to 12499 & 52 & 4.32 \\
12500 to 14999 & 32 & 2.66 \\
15000 to 17499 & 27 & 2.24 \\
17500 to 19999 & 26 & 2.16 \\
20000 to 22499 & 51 & 4.23 \\
22500 to 24999 & 42 & 3.49 \\
25000 to 29999 & 67 & 5.56 \\
30000 to 34999 & 97 & 8.05 \\
35000 to 39999 & 93 & 7.72 \\
40000 to 49999 & 154 & 12.78 \\
50000 to 59999 & 112 & 9.29 \\
60000 to 74999 & 12 & 8.96 \\
75000 to 89999 & 108 & 6.89 \\
90000 to 109999 & 83 & 4.4 \\
110000 to 129999 & 53 & 3.24 \\
130000 to 149999 & 39 & 1 \\
150000 or 0 ver & 12 & 100 \\
\hline Total & & 1.66 \\
\hline
\end{tabular}


Table 7 Respondent's income (Rincome) variables

\begin{tabular}{|c|c|c|c|c|c|}
\hline \multirow{2}{*}{$\begin{array}{l}\text { Rincome } \\
=1 \text { "Far Below Average" }\end{array}$} & \multicolumn{2}{|c|}{ Rincome $^{1} \approx$ US Census } & \multicolumn{2}{|c|}{ Rincome $^{2}$ (Cat 1,2 \& $3 \neq$ US Census) } & \multirow{2}{*}{$\begin{array}{l}\text { Rincome }^{3} \approx \% \text { Fincome } \\
5.48 \% \approx 6.72 \%\end{array}$} \\
\hline & $29.46 \%$ & Rincome $\leq 24999$ & $6.8 \%$ & Rincome $\leq 5999$ & \\
\hline$=2$ "Below Average" & $34.11 \%$ & $25000>$ Rincome $\leq 49999$ & $22.66 \%$ & $6000>$ Rincome $\leq 24999$ & $20.5 \% \approx 21.33 \%$ \\
\hline$=3$ "Average" & $18.26 \%$ & $50000>$ Rincome $\leq 74999$ & $52.37 \%$ & $25000>$ Rincome $\leq 74999$ & $46.89 \% \approx 48.71 \%$ \\
\hline$=4$ "Above Average" & $11.29 \%$ & $75000>$ Rincome $\leq 109999$ & $11.29 \%$ & $75000>$ Rincome $\leq 109999$ & $24.48 \% \approx 22.41 \%$ \\
\hline$=5$ "Far Above Average" & $6.89 \%$ & $110000>$ Rincome & $6.89 \%$ & $110000>$ Rincome & $2.66 \% \approx 0.83 \%$ \\
\hline
\end{tabular}

Cat 1,2 \& 3 refer to the shares of respondents falling in categories "Far Below Average", "Below Average" \& "Average" 
Table 8 Descriptives of IMI measures

\begin{tabular}{|c|c|c|c|c|c|c|}
\hline \multirow[t]{2}{*}{ Rincome categories } & \multicolumn{2}{|c|}{ Mind ${ }^{1}$} & \multicolumn{2}{|c|}{1 Mind $x^{2}$} & \multicolumn{2}{|c|}{ IMind $x^{3}$} \\
\hline & Frequency & $\%$ & Frequency & $\%$ & Frequency & $\%$ \\
\hline$=-4$ & 5 & 0.41 & 1 & 0.08 & 1 & 0.08 \\
\hline$=-3$ & 55 & 4.56 & 19 & 1.58 & 15 & 1.24 \\
\hline$=-2$ & 259 & 21.49 & 74 & 6.14 & 68 & 5.64 \\
\hline$=-1$ & 367 & 30.46 & 307 & 25.48 & 248 & 20.58 \\
\hline$=0$ & 267 & 22.16 & 443 & 36.76 & 475 & 39.42 \\
\hline$=1$ & 152 & 12.61 & 240 & 19.92 & 279 & 23.15 \\
\hline$=2$ & 76 & 6.31 & 97 & 8.05 & 94 & 7.80 \\
\hline$=3$ & 20 & 1.66 & 20 & 1.66 & 25 & 2.07 \\
\hline$=4$ & 4 & 0.33 & 4 & 0.33 & . & \\
\hline Total & $N=1,205$ & 100 & $N=1,205$ & 100 & $N=1,205$ & \\
\hline \multicolumn{7}{|l|}{ IMI } \\
\hline 0 if 1 Mind $x=0$ & 267 & 22.16 & 443 & 36.76 & 475 & 39.42 \\
\hline 1 if $/$ Mind $x \neq 0$ & 938 & 77.84 & 762 & 63.24 & 730 & 60.58 \\
\hline Total & $N=1,205$ & 100 & $N=1,205$ & 100 & $N=1,205$ & 100 \\
\hline \multicolumn{7}{|l|}{ IMlup } \\
\hline 0 if 1 Mind $x=0$ & 267 & 51.45 & 443 & 55.10 & 475 & 54.41 \\
\hline 1 if $/$ Mindx $>0$ & 252 & 48.55 & 361 & 44.90 & 398 & 45.59 \\
\hline Total & $N=519$ & 100 & $N=804$ & 100 & $N=873$ & 100 \\
\hline \multicolumn{7}{|l|}{ IMIdown } \\
\hline 0 if 1 Mind $x=0$ & 267 & 28.02 & 443 & 52.49 & 475 & 58.86 \\
\hline 1 if IMind $x<0$ & 686 & 71.98 & 401 & 47.51 & 332 & 41.14 \\
\hline Total & $N=953$ & 100 & $N=844$ & 100 & $N=807$ & 100 \\
\hline
\end{tabular}

Table 9 Evidence for positive assortative mating

Correlations (N)

Education

Respondent and spouse's degrees (highest)

$0.4667(1,203)$

Respondent and spouse's years of school

$0.5476(1,200)$

Job prestige scores

Respondent and spouse

$0.3066(1205)$

Mother and father

$0.3841(1205)$

Table 10 Diffspousemother: predicting income mobility

\begin{tabular}{ll}
\hline & Correlations (N) \\
\hline Spouse's job prestige score and Rincome & $0.1907(1205)$ \\
Mother's job prestige score and Fincome & $0.2458(1205)$ \\
Diffspousemother and IMI & $-0.0827(1205)$ \\
Diffspousemother and respondent's job prestige score & $0.0507(1205)$ \\
Mother's and respondent's job prestige scores & $0.2257(1205)$ \\
\hline
\end{tabular}


Table 11 Ocuppations \& prestige scores

\begin{tabular}{|c|c|c|}
\hline 1980 Census occupational category & 1980 Census code & 1989 GSS prestige score \\
\hline Miscellaneous Food Preparation Occupations & 444 & 17 (min) \\
\hline Legislators & 3 & 61 \\
\hline Chief Executives and General Admin., Public Admin. & 4 & 70 \\
\hline Administrators and Officials, Public Administration & 5 & 51 \\
\hline Administrators, Protective Service & 6 & 54 \\
\hline Financial Managers & 7 & 59 \\
\hline Personnel and Labor Relations Managers & 8 & 54 \\
\hline Purchasing Managers & 9 & 63 \\
\hline Managers, Marketing, Advertising, and Public Relations & 13 & 59 \\
\hline Administrators, Education and Related Fields & 14 & 64 \\
\hline Managers, Medicine and Health & 15 & 69 \\
\hline Managers, Properties and Real Estate & 16 & 39 \\
\hline Postmasters and Mail Superintendents & 17 & 53 \\
\hline Funeral Directors & 18 & 49 \\
\hline Managers and Administrators, n.e.c. & 19 & 51 \\
\hline Accountants and Auditors & 23 & 65 \\
\hline Underwriters & 24 & 48 \\
\hline Other Financial Officers & 25 & 48 \\
\hline Management Analysts & 26 & 61 \\
\hline Personnel, Training, and Labor Relations Specialists & 27 & 43 \\
\hline Purchasing Agents and Buyers, Farm Products & 28 & 42 \\
\hline Business and Promotion Agents & 34 & 51 \\
\hline Construction Inspectors & 35 & 47 \\
\hline Inspectors/Compliance Officers, Except Construction & 36 & 50 \\
\hline Management Related Occupations, n.e.c. & 37 & 49 \\
\hline Architects & 43 & 73 \\
\hline Aerospace Engineers & 44 & 72 \\
\hline Economics Teachers & 119 & 74 \\
\hline Physicians & 84 & 86 (max) \\
\hline
\end{tabular}

Note: This is an extract from the 1989 GSS occupational prestige rating at: http://publicdata.norc.org:41000/gss/documents/ BOOK/GSS_Codebook.pdf, Appendix F

\section{Competing interests}

The IZA Journal of Labor and Development is committed to the IZA Guiding Principles of Research Integrity. The author declares that she has observed these principles.

\section{Acknowledgements}

The author is grateful to her supervisor, Fidel Perez, Department of Economic Analysis, University of Alicante, for his patient guidance, encouragement and helpful advice. She would also like to thank for feedback on a previous version to Elena Martinez Sanchis, David Cuberes, Asier Mariscal, Juan Mora, Pedro Albarran and Lola Collado. She would also like to acknowledge useful feedback from Kirill Borissov at the XV Conference on International Economics and from several anonymous referees. Funding from the Department of Economic Analysis, University of Alicante, and from the European Commission, Joint Research Centre (JRC), is gratefully acknowledged.

Responsible editor: Hartmut Lehmann

Received: 9 April 2015 Accepted: 11 August 2015

Published online: 25 September 2015

\section{References}

Aaberge R, Bjorklund A, Jantti M, Palme M, Pedersen PJ, Smith N, Wennemo T (2002) Income inequality and income

mobility in the scandinavian countries compared to the United States. Rev Income Wealth 48:443-469

Acemoglu D, Robinson JA (2001) A theory of political transitions. Am Polit Sci Rev 95(3):649-661. Sept. 2011

Aghion P, Algan Y, Cahuc P, Shleifer A (2010) Regulation and distrust. Q J Econ, MIT Press 125(3):1015-1049

Alesina A, La Ferrara E (2002) Who trusts others? J Public Econ 85:207-234

Algan Y, Cahuc P (2010) Inherited trust and growth. Am Econ Rev 100:2060-92

Arrow KJ (1974) The Limits of organization (1st edn), Norton, New York 
Blundell RW, Smith RJ (1993) Simultaneous microeconometric models with censored or qualitative dependent variables. In: Maddala GS, Rao CR, Vinoc HD (eds). Handbook of Statistics, Vol. II. Elsevier, Amsterdam

Chadwick L, Solon G (2002) Intergenerational income mobility among daughters. Am Econ Rev 92(1):335-344

Chiappori P-A, Iyigun M, Weiss Y (2009) Investment in schooling and the marriage market. Am Econ Rev 99(5):1689-1713

Davis JA, Smith TW, Hodge RW, Nakao K, Treas J (1991) Occupational prestige ratings from the 1989 general social survey. Chicago, IL: National Opinion Research Center [producer], 1991. Ann Arbor, MI: Inter-university Consortium for Political and Social Research [distributor]. http://doi.org/10.3886/ICPSR09593.v1

Dohmen T, Falk A, Huffman D, Sunde U (2012) The intergenerational transmission of risk and trust attitudes. Rev Econ Stud 79:645-677

Domingue B, Fletcher J, Conleye D, Boardman JD (2014) Genetic and educational assortative mating among US adults. Proc Natl Acad Sci 111(22):7996-8000

Ermisch J, Gambetta D (2011) The long shadow of income on trustworthiness. Sociol Work Pap 3:1-35

Ermisch J, Francesconi M, Siedler T (2006) Intergenerational economic mobility and assortative mating. Econ J 116:659-679

Feigenbaum JJ (2014) A new old measure of intergenerational mobility: lowa 1915 to 1940. http://scholar.harvard.edu/ files/jfeigenbaum/files/feigenbaum___intergenerational_mobility_-_10-21-14.pdf

Fischer J, Torgler B (2006) The effect of relative Income position on social capital. Econ Bull 26(4):1-20

Freeman R-B, Katz L-F (1995) Introduction and summary, in differences and changes in wage structures. Richard, B. Freeman and Lawrence F. Katz, eds. Chicago: University of Chicago Press, pp. 1-22. Cited in Solon, G (2002), Cross-Country Differences in Intergenerational Earnings Mobility. The Journal of Economic Perspectives, Vol. 16, No. 3, pp 59-66

Gottschalk P (1997) Inequality, income growth, and mobility: the basic facts. J Econ Perspect 11(2):21-40

Gottschalk P, Smeeding T-M (1997) Cross-national comparisons of earnings and income inequality. J Eco Lit 35: 2, pp 633-87. Cited in Solon, G. (2002), Cross-Country Differences in Intergenerational Earnings Mobility. The Journal of Economic Perspectives, Vol. 16, No. 3, pp. 59-66

Jones A (2005) Applied econometrics for health economists. A Practical Guide. Prepared for the Office of Health Economics 2005

La Porta R, Lopez-de-Silanes F, Shleifer A, Vishny R (1997) Trust in large organizations. Am Econ Rev, Am Econ Assoc 87(2):333-38

Luo SH, Klohnen EC (2005) Assortative mating and marital quality in newlyweds: a couple-centered approach. J Pers Soc Psychol 88:304-326

Marshall A (1961) Principles of economics, London: Macmillan. Cited in Fischer J. and B. Torgler (2006), The Effect of Relative Income Position on Social Capital. Econ Bull 26(4):1-20

Marx K (1849) Wage labour and capital in selected works, Vol.1, by K. Marx and F. Engels, Moscow: Progress Publishers, Cited in Fischer J. and B. Torgler (2006), The Effect of Relative Income Position on Social Capital. Econ Bull 26(4):1-20

Mazumder B, Acosta M (2015) Using occupation to measure intergenerational mobility. ANNALS Am Acad Polit Soc Sci 657(1):174-193

Millo G, Pasini G (2010) Does social capital reduce moral hazard? A network model for non-Life insurance demand. Fisc Stud, Inst Fisc Stud 31(3):341-372. 09

Paxton P (2007) Association memberships and generalized trust: a multilevel model across 31 countries. Soc Forces 86(1):47-76

Piff P-K, Kraus M-W, Cheng B-H, Keltner D (2010) Having less, giving more: the influence of social class on prosocial behavior. J Pers Soc Psychol 99(5):771-784

Putnam R (1993) Making democracy, work: civic traditions in Modern Italy. Princeton University Press, Princeton, NJ

Solon G (1992) Intergenerational Income Mobility in the United States. Am Econ Rev, Publ Am Econ Assoc 82(3):393-408

Solon, G (2002) Cross-country differences in intergenerational earnings mobility. J Econ Perspect 16(3):59-66

Smith A (1759/1976) Theory of moral sentiments, Oxford: Clarendon Press. Cited in Fischer J. and B. Torgler (2006), The Effect of Relative Income Position on Social Capital. Econ Bull 26(4):1-20

Smith T-W, Marsden P, Hout M, Kim J (2013) General social surveys, 1972-2012 [machine-readable data file] /Principal Investigator, Tom W. Smith; Co-Principal Investigator, Peter V. Marsden; Co-Principal Investigator, Michael Hout; Sponsored by National Science Foundation. -NORC ed.- Chicago: National Opinion Research Center [producer]; Storrs, CT: The Roper Center for Public Opinion Research, University of Connecticut [distributor],

Stiglitz J (2000) Formal and informal institutions. In: Dasgupta P, Serageldin I (eds). Social Capital: A Multifaceted Perspective. World Bank, Washington, DC

Thurow L (1973) The political economy of income redistribution policies. ANNALS Am Acad Polit Soc Sci 409:146-155 Van Lange P, Vinkhuyzen A, Posthuma D (2014) Genetic influences are virtually absent for trust. PLoS ONE 9(4):e93880 Zak P, Knack S (2001) Trust and growth. Econ J, R Econ Soc 111(470):295-321

Zak, P, Knack S (2002) Building trust: public policy, interpersonal trust, and economic development. Supreme Court Econ Rev 10:91-107 